\title{
Oncogene expression in primary myelodysplasia: Correlation with haematological, karyotypic, and clinical progression
}

\author{
R M Hutchinson, J H Pringle, S C Knight, I Lauder, A Potter, C Jagger
}

\begin{abstract}
Aims: To see if the relative expressions of proto-oncogenes that are increased in acute myeloid leukaemia are raised in patients with myelodysplastic syndromes (MDS), and to see if they increase with progression to leukaemia. To note if there is a correlation between morphology, karyotype, and these protooncogene expressions and if any one proto-oncogene can predict prognosis.

Method: Bone marrow from 130 patients was analysed at six monthly intervals over two years for relative mRNA expression of seven oncogenes, karyotype, and morphology. The technique used slot blot hybridisation and densitometric analysis. The results were compared with 14 surgical controls and 30 people with vitamin deficiency anaemia.

Results: Six of seven oncogenes showed increased expression which progressed with time, but did not correlate with morphological or karyotypic changes. Expression of four of the seven oncogenes was increased in megaloblastic and iron deficiency anaemia. $C$-mos showed differences among the five morphological subgroups; it correlated with abnormal location $(p=0.025)$ and seemed to influence prognosis.

Conclusion: Increased proto-oncogenes reflect the overall marrow perturbation in MDS. C-mos may reflect persistence of monocyte pathway which confirms marrow stability.
\end{abstract}

Department of

Haematology,

Leicester Royal

Infirmary, Leicester LE1 5WW

R M Hutchinson

Department of

Pathology, University of Leicester, Leicester

$\mathrm{J} H$ Pringle

I Lauder

S C Knight

Department of

Human Genetics,

University of Sheffield

A Potter

Department of Community Health, University of Leicester C Jagger

Correspondence to: Dr R M Hutchinson

Accepted for publication 1 October 1991 The myelodysplastic syndromes (MDS) represent a morphologically distinct group of pre-leukaemic conditions. They are relatively common among haematological malignancies. The age specific incidence rate is $3.60 / 100000$ population with a relative risk of 102.5 in Leicestershire $^{1}$ (range 80 to 120 ). ${ }^{1}$ Forty per cent of patients with MDS may progress over months into acute myeloid leukaemia (AML). Serial studies into the pathogenesis have been made on such patients. The syndromes are well recognised on morphological grounds, but little is known about the aetiology.

Chromosomal abnormalities are present in both MDS and AML and carry a variable prognosis. $^{2}$

Proto-oncogenes are genes which control normal cellular proliferation and differentiation. Genetic alteration in their structure or regulation results in oncogene activation, disordered control, and neoplasia. However, altered expression may arise from the disease state rather than direct genetic mutation. In AML $N$-ras and $c-m y c$ may be activated by point mutation, gene amplification, or translocation. ${ }^{3} C$-myb, $c$-mos, $c$-erb B1, c-fos and $c$ ets are also increased in expression. ${ }^{4} \mathrm{~N}$-ras oncogene point mutations occur in up to $40 \%$ of cases with $\mathrm{MDS}^{5}$ and loss of the mutant form may accompany clinical remission. ${ }^{6}$ But the role of $c-m y c, c-m y b$, and other oncogenes found in both MDS and AML is not clear. ${ }^{7-8}$

We therefore investigated a cohort of 130 patients over two years and studied pathogenesis at the chromosomal and molecular level to ascertain if there was any correlation with specific oncogene activation.

\section{Methods}

Primary myelodysplastic syndrome (MDS) was diagnosed on peripheral blood and bone marrow samples according to the FAB criteria ${ }^{9}$ in 130 consecutive patients presenting to the haematology department from 1987 to 1989. The study was approved by the local ethics committee and patients gave informed consent. Conventional Romanowsky dyes were used. Patients with vitamin B12 and folate deficiencies and those developing MDS secondary to another haematological malignancy were excluded. Bone marrow samples were submitted for karyotype and oncogene studies at six monthly intervals. No patient in the study received cytotoxic drugs.

The control group comprised 14 haematologically normal patients undergoing cold surgery. Ten patients with megaloblastic anaemia and 10 with iron deficiency anaemia were also studied.

Cytogenetic analysis was performed at diagnosis and at six monthly intervals by conventional techniques with 24 hour cultures on bone marrow using short and long term exposure to colcimid. Thirty metaphases were counted and a minimum of 10 cells studied by conventional banding.

Bone marrow $(5 \mathrm{ml})$ was taken at presentation from patients and the control group, and mononuclear cells were obtained by standard Ficoll-hypaque density centrifugation. The cells were controlled rate frozen and stored in 
Table 1 Oncogene probes used for detection of expression

\begin{tabular}{|c|c|c|c|c|}
\hline Oncogene & $\begin{array}{l}\text { Cellular location of } \\
\text { oncoprotein }\end{array}$ & Chromosome & Probe & Reference \\
\hline $\begin{array}{l}v \text {-abl (mouse) } \\
c \text {-erbB } 1 \text { (human) } \\
c \text {-etsI (human) } \\
c-f o s \text { (mouse) } \\
c-\text { os (human) } \\
c-m y c \text { (human) } \\
c-m y b \text { (human) }\end{array}$ & $\begin{array}{l}\text { Cytoplasmic } \\
\text { Plasma membrane } \\
\text { Cytoplasmic } \\
\text { Nucleus } \\
\text { Nucleus } \\
\text { Nucleus }\end{array}$ & $\begin{array}{l}9 \mathrm{q} 34 \\
7 \mathrm{p} 13 \\
1 \cdot 11 \mathrm{q} 23 / 24 \\
8 \mathrm{q} 22 \\
2 \mathrm{q} 21 \\
8 \mathrm{q} 24 \cdot 1 \\
6 \mathrm{q} 22\end{array}$ & $\begin{array}{l}1.9 \mathrm{~kb} \text { SacI-Hind III } \\
2.4 \mathrm{~kb} \text { ClaI fragment } \\
5.4 \mathrm{~kb} \text { EcoRI fragment } \\
600 \mathrm{pb} \text { KpnI-Hind IIII } \\
1 \mathrm{~kb} \text { Sau } 3 a \text { fragment } \\
1.5 \mathrm{~kb} \text { SacI fragment } \\
1.74 \mathrm{~kb} \text { KpnI-Hind III }\end{array}$ & $\begin{array}{l}\text { Reddy et al, } 1983^{30} \\
\text { Xu et al, } 1984^{31} \\
\text { De Taisne et al, } 1984^{32} \\
\text { Oskarsson et al, } 1980^{33} \\
\text { Trus et al, } 1982^{34} \\
\text { Dalla et al, } 1983^{35} \\
\text { Klempnauer et al, } 1982^{36}\end{array}$ \\
\hline
\end{tabular}

vapour phase liquid nitrogen for subsequent analysis.

Total RNA was extracted by homogenisation in guanadinium thiocyanate and purified by caesium chloride centrifugation. The integrity of the RNA was assessed by electrophoresis in a $1.0 \%$ agarose gel and stained with ethidium bromide. A $28 \mathrm{~S}: 18 \mathrm{~S}$ ribosomal RNA ratio of less than 2:1 or fragmentation of either of these species was taken as evidence of degradation. Any sample showing evidence of extensive degradation was discarded because negative results can reflect degradation of the RNA rather than the absence of transcripts in the sample.

The total RNA was precipitated in 2.5 volumes of ethanol and resuspended at $20 \mu \mathrm{g} /$ $\mathrm{ml}$, denatured for 10 minutes in a solution containing $7.5 \%$ formaldehyde and $6 \times$ SSC (saline sodium citrate), cooled, and $20 \mu \mathrm{g}$ applied to Hybond $\mathrm{C}$ membrane (Amersham UK) using slot blotting manifold. ${ }^{10}$ Filters were then placed in an oven for two hours at $80^{\circ} \mathrm{C}$ to bake the RNA on to the membrane. Each membrane included control slots containing RNA samples from the HL60 cell line and yeast ribosomal RNA as well as vector DNA. Exon sequences from molecular cloned c-oncogene probes (table 1) were excised from the recombinant sequences by restriction endonuclease digestion and were ${ }^{32} \mathbf{P}$ labelled using the method outlined by Feinberg and Volgelstein. ${ }^{11}$ The RNA membranes were hybridised using methods previously described by Grosso and Pitot ${ }^{12}$ and hybridisation was detected by autoradiography at $-70^{\circ} \mathrm{C}$ with an intensifying screen. (Dupont Cronex) using preflashed X-OMAT AR film (Kodak). The level or intensity of the slot was quantified by densitometry using a laser scanning densitometer (Pharmcia/LKB)..$^{13}$

The probes were initially evaluated using total RNA from the cell line HL60 to establish the required stringency for specific

Table 2 Characteristics of patients at diagnosis and their disease subgroup and karyotype

\begin{tabular}{lcclll}
\hline & & & & \multicolumn{2}{l}{$\%$ Karyotype } \\
\cline { 5 - 6 } Disease & $N=$ & Sex $M / F$ & Mean age & Abnormal & Normal \\
\hline RA & 69 & $36 / 23$ & $75(55-90)$ & 26 & 74 \\
SA & 21 & $10 / 11$ & $79 \cdot 9(65-90)$ & 19 & 81 \\
CMML & 14 & $7 / 7$ & $76 \cdot 1(60-88)$ & 9 & 91 \\
RAEB & 24 & $14 / 10$ & $79(63-86)$ & 36 & 67 \\
RAEBT & 12 & $8 / 4$ & $73(63-93)$ & 83 & 17 \\
Total & 130 & $75 / 55$ & $77(55-90)$ & 30 & \\
\hline
\end{tabular}

RA refractory anaemia; SA sideroblastic anaemia; CMML chronic myelomonocytic leukaemia; RAEB refractory anaemia with excess of blasts; RAEBT refractory anaemia with excess of blasts in transformation. hybridisation. The expression of each patient's RNA was determined relative to the HL60 cell line RNA sample for each probe. Samples were repeated when sufficient RNA had been extracted.

The oncogene data were submitted to a Kruskal-Wallis non-parametric one-way analysis variance. Where significant differences between groups were ascertained the groups were then tested pairwise to establish specific pairwise differences. The survival analysis involved fitting Cox's proportional hazards regression model to the survival time from date of entry to the study to assess the significance of prognostic factors.

\section{Results}

PATIENT CHARACTERISTICS (table 2)

The age of the 130 patients with MDS ranged from 55-90 years (median 77) at time of diagnosis. This compared with a range of 41-88 (median 59) for the controls. The excess of men with MDS was confirmed. Our series contained a predominance with refractory anaemia (RA) $26 \%$ of which had an abnormal karyotype. As expected, in $83 \%$ of patients with refractory anaemia with excess of blasts in transformation (RAEBT) there were chromosomal abnormalities. One of the controls had a missing $Y$ chromosome and another a minus 12 . There was no correlation between specific disease category and any one individual chromosomal gain or loss.

\section{ONCOGENE EXPRESSION (table 3)}

All proto-oncogenes in marrow samples from patients with MDS, except $c$-erbB, were significantly increased in their relative messenger RNA transcription when compared with normal control marrows. However, of all the seven oncogenes tested, only $c$-mos mRNA concentrations differentiated between the morphological MDS subgroups ( $p=0.041$ ) (table 4). It was lowest in sideroblastic anaemia (SA) and highest in chronic myelomonocytic leukaemia (CMML). It increased as RA evolved into RAEBT and AML, but this trend did not reach significance.

\section{PROTO-ONCOGENE EXPRESSION IN} MEGALOBLASTIC AND IRON DERICIENCY ANAEMIAS

Table 5 shows the relative expressions of the four oncogenes which were significantly raised in this third group of patients. $C$-myc, $c$-ets, and $c$-fos were increased in both disorders; increased $c$-abl expression occurred in iron deficiency anaemia alone. 
Table 3 Proto-oncogene expression in MDS and in controls with morphologically normal marrow

\begin{tabular}{|c|c|c|c|c|c|c|c|}
\hline Oncogene & MDS expression & Number & Range & Normal expectancy & Number & Range & p Value \\
\hline $\begin{array}{l}c-m o s \\
c-m y b \\
c-m y c \\
c-e t s \\
c-a b l \\
c-f o s \\
c-e r b B\end{array}$ & $\begin{array}{c}0 \cdot 7 \\
2 \cdot 3 \\
1 \cdot 26 \\
17 \cdot 13 \\
3 \cdot 19 \\
1.85 \\
2.09\end{array}$ & $\begin{array}{l}66 \\
61 \\
72 \\
59 \\
54 \\
59 \\
33\end{array}$ & $\begin{array}{l}0.05,9 \cdot 7 \\
0 \cdot 04,28 \cdot 8 \\
0 \cdot 004,126 \cdot 7 \\
0 \cdot 1,681 \\
0 \cdot 1,46 \cdot 1 \\
0 \cdot 07,75 \cdot 1 \\
0 \cdot 45,15 \cdot 8\end{array}$ & $\begin{array}{l}0 \cdot 175 \\
0 \cdot 162 \\
0 \cdot 275 \\
0.55 \\
0 \cdot 23 \\
0 \cdot 43 \\
1 \cdot 48\end{array}$ & $\begin{array}{l}9 \\
8 \\
9 \\
9 \\
8 \\
8 \\
9\end{array}$ & $\begin{array}{l}0 \cdot 05,1 \cdot 45 \\
0 \cdot 06,3 \cdot 35 \\
0 \cdot 012.0 \cdot 65 \\
0 \cdot 075,16 \cdot 75 \\
0 \cdot 18,5 \cdot 5 \\
0 \cdot 11,0 \cdot 95 \\
0 \cdot 09,3 \cdot 8\end{array}$ & $\begin{array}{l}0.006 \\
0.0006 \\
0.0008 \\
0.0005 \\
0.005 \\
0.001 \\
0.55\end{array}$ \\
\hline
\end{tabular}

Table 4 -mos oncogene expression according to disease category

\begin{tabular}{lllllll}
\hline Disease & $S A$ & $R A$ & $R A E B$ & $R A E B T$ & $C M M L$ & $p$ Value \\
\hline $\mathrm{N}=$ & 11 & 23 & 11 & 6 & 9 \\
c-mos oncogene expression (median) & 0.38 & 0.55 & 1.19 & 1.3 & 1.57 & 0.041 \\
Range & $0.08,5.2$ & $0.05,6.7$ & $0.55,9.7$ & $0.34,4.3$ & $0.37,3.9$ & \\
\hline
\end{tabular}

Table 5 Relative median expression of proto-oncogene mRNA in normal subjects and those with iron deficient and megaloblastic anaemias

\begin{tabular}{|c|c|c|c|c|c|c|c|c|c|c|}
\hline \multirow[b]{2}{*}{ Probe } & \multicolumn{3}{|c|}{ Normal } & \multicolumn{3}{|c|}{ Iron deficiency anaemia } & \multicolumn{3}{|c|}{ Megaloblastic anaemia } & \multirow[b]{2}{*}{ p Value } \\
\hline & $\operatorname{Exp}$ & $N=$ & Range & $E c p$ & $N=$ & Range & $\operatorname{Exp}$ & $N=$ & Range & \\
\hline $\begin{array}{l}c-m y c \\
c-e t s \\
c-a b l \\
c-f o s \\
c-m o s\end{array}$ & $\begin{array}{l}0.275 \\
0.55 \\
0 \cdot 23 \\
0.43 \\
0.75\end{array}$ & $\begin{array}{l}9 \\
9 \\
8 \\
8 \\
9\end{array}$ & $\begin{array}{l}0.008,0 \cdot 5 \\
0 \cdot 06,13 \cdot 4 \\
0 \cdot 15,4 \cdot 4 \\
0 \cdot 11,0 \cdot 95 \\
0 \cdot 039,1 \cdot 16\end{array}$ & $\begin{array}{c}3 \cdot 11 \\
44 \cdot 2 \\
3 \cdot 20 \\
2 \cdot 27 \\
0 \cdot 68\end{array}$ & $\begin{array}{l}6 \\
6 \\
5 \\
6 \\
6\end{array}$ & $\begin{array}{l}0 \cdot 05,21 \cdot 6 \\
3 \cdot 95,170 \cdot 2 \\
1 \cdot 51,15 \cdot 68 \\
0 \cdot 3,73 \cdot 0 \\
0 \cdot 06,2 \cdot 06\end{array}$ & $\begin{array}{l}5.26 \\
3 \cdot 22 \\
0.28 \\
1.43 \\
0.93\end{array}$ & $\begin{array}{l}4 \\
4 \\
3 \\
4 \\
4\end{array}$ & $\begin{array}{l}0 \cdot 98,46 \cdot 73 \\
0 \cdot 35,68 \cdot 1 \\
0 \cdot 26,8 \cdot 52 \\
0 \cdot 39,68 \cdot 0 \\
0 \cdot 28.256\end{array}$ & $\begin{array}{l}0.004 \\
0.01 \\
0.05 \\
0.04 \\
0.09\end{array}$ \\
\hline
\end{tabular}

PROTO-ONCOGENE AND KARYOTYPE (table 6)

Forty patients had an abnormal karyotype. Among these there was an association between $5 \mathrm{q}-$ and reduced $c-a b l ; 7 \mathrm{q}-$ and increased $c$-ets, $c$-abl, and $c$-fos. However, only c-mos showed any correlation between oncogene location (on chromosome 8$)$ and expression $(p=0.025)$. Patients with trisomy 8 had greater c-mos expression than those diploid for 8 $(\mathrm{p}=0.036)$.

\section{PROGRESSION OVER TWO YEARS}

As expected, $66 \%$ of those patients with RAEBT had died by the end of the study period-all from marrow failure. In contrast, $79 \%$ of those with CMML, though having a high overall oncogene expression, were still alive two years after diagnosis. Table 7 shows that $c-m o s, c-m y b$, and $c-m y c$ all significantly increased in relative gene expression over time. This did not correlate with clinical, morphological, or karyotypic changes. Sixty two per cent of patients with SA had a progressive rise in the above oncogene activity but remained clinically stable with no change into a more malignant form of MDS. There was, however, a trend to an increase in their transfusion requirements with increasing erythroid hyperplasia. Unfortunately it was not possible to quantitate the degree of ineffective erythropoiesis in these patients. Those patients transforming from RA to RAEBT over the study period showed a greater difference in the increase in expression of all three oncogenes compared with patients with SA and CMML who did not progress into the more malignant subgroups of MDS.

Morphological progression occurred in $25 \%$ of the 130 patients; $7 \cdot 5 \%$ progressed to AML. Presentation diagnoses were SA in two, CMML in one, RAEB in five and RAEBT in two. In $70 \%$ of those with AML the karyotype was abnormal at presentation and in $20 \%$ it became abnormal with the change to AML. Four patients had 5q-, three 7q-, two trisomy 8 and one minus 8 . In our study of the 19 patients who died with an abnormal karyotype 12 were hypodiploid and seven hyperdiploid.

Survival curves were plotted using life table survival estimates and differences between groups assessed by logrank tests. The median survival for RA, SA, and CMML had not been reached by two years. That for RAEB and RAEBT was 12 months $(p=0.0007)$. Trisomy 8 conferred a survival advantage in RA, SA, and CMML, but not in RA progressing to RAEBT $(p=0.7)$. Similarly, a $c$-mos expression of $>0.6$ at presentation in these three subgroups suggested a trend towards longer survival (figure).

\section{Discussion}

Unlike chronic myeloid leukaemia (CML), characterised by the Philadelphia chromosome and $b c r / a b l$ fusion oncogene, no one specific chromosomal abnormality or oncogene activation is pathognomonic for the myelodysplastic syndrome. In our study $c-m y c, c-m y b, c-m o s, c-$ $a b l$ and $c$-ets expressions were increased and increased with progression of each disorder.

Table 6 Proto-oncogene expression and karyotype in 40 patients with $M D S$

\begin{tabular}{lrr}
\hline $\begin{array}{l}\text { Chromosomal } \\
\text { abnormality }\end{array}$ & Oncogene affected & $p$ Value \\
\hline-5 & Reduced $c$-abl & 0.066 \\
-7 & Increased $c$-ets & 0.019 \\
& $c-a b l$ & 0.062 \\
$c-$ fos & 0.050 \\
+8 & Increased $c$-mos & 0.025 \\
\hline
\end{tabular}


Table 7 Change of proto-oncogene expression over time

\begin{tabular}{|c|c|c|c|c|c|c|}
\hline \multirow[b]{2}{*}{ Oncogene } & \multirow[b]{2}{*}{$N=$} & \multicolumn{2}{|c|}{ Median expectancy at time } & \multirow[b]{2}{*}{ Median difference } & \multirow[b]{2}{*}{ Range } & \multirow[b]{2}{*}{ p Value } \\
\hline & & 0 & 2 years & & & \\
\hline $\begin{array}{c}R A-R A E \\
c-m o s \\
c-m y b \\
c-m y c\end{array}$ & $\begin{array}{l}7 \\
7 \\
6\end{array}$ & $\begin{array}{l}0.44 \\
0.62 \\
0.47\end{array}$ & $\begin{array}{l}1 \cdot 19 \\
7 \cdot 34 \\
7 \cdot 34\end{array}$ & $\begin{array}{l}0.43 \\
7 \cdot 19 \\
6 \cdot 49\end{array}$ & $\begin{array}{l}(0,7 \cdot 43) \\
(-1 \cdot 18,17 \cdot 20) \\
(0 \cdot 26,94 \cdot 13)\end{array}$ & $\begin{array}{l}0.06 \\
0.09 \\
0.04\end{array}$ \\
\hline $\begin{array}{c}S A-S A: \\
c-m o s \\
c-m y b \\
c-m y c\end{array}$ & $\begin{array}{r}13 \\
9 \\
9\end{array}$ & $\begin{array}{l}0.31 \\
1.01 \\
1.00\end{array}$ & $\begin{array}{l}2 \cdot 72 \\
4 \cdot 40 \\
8.99\end{array}$ & $\begin{array}{l}2 \cdot 14 \\
3 \cdot 23 \\
7 \cdot 85\end{array}$ & $\begin{array}{l}(0 \cdot 07,11 \cdot 77) \\
(-1 \cdot 0,11 \cdot 36) \\
(0,83 \cdot 73)\end{array}$ & $\begin{array}{l}0.002 \\
0.013 \\
0.014\end{array}$ \\
\hline $\begin{array}{c}C M M L-C \\
c-m o s \\
c-m y b \\
c-m y c\end{array}$ & $\begin{array}{l}7 \\
7 \\
7\end{array}$ & $\begin{array}{l}1.25 \\
2.60 \\
0.38\end{array}$ & $\begin{array}{l}3.84 \\
4.53 \\
5.76\end{array}$ & $\begin{array}{l}1.34 \\
3.05 \\
5.44\end{array}$ & $\begin{array}{l}(0.37,3 \cdot 97) \\
(0,24 \cdot 29) \\
(-0.74,10 \cdot 29)\end{array}$ & $\begin{array}{l}0.022 \\
0 \cdot 100 \\
0.36\end{array}$ \\
\hline
\end{tabular}

But c-myc, c-ets, and c-abl also showed increased expression in the non-neoplastic conditions of megaloblastic anaemia and iron deficiency anaemia. Nuclear $c-m y c$ oncoprotein is present throughout the cell cycle in normal bone marrow but most often expressed in more primitive myeloid cells and those in the G0/G1 phase of the cycle. And it is more expressed in myeloid and early erythroid cell populations. ${ }^{14-15} C-m y c$ expression inversely correlates with the state of cell differentiation. ${ }^{12}$ In both MDS and megaloblastic anaemia cells are held up in G0/G1 and there is often a myeloid maturation arrest. In iron deficiency anaemia the myeloid:erythroid ratio is reversed as additional erythroid mitotic division occurs with an emphasis on the early basophilic and late orthochromic normoblasts along with intramedullary cell death. ${ }^{16}$ All these features promote increased $c-m y c$ expression. In contrast, $c-m y b$ RNA expression was raised in MDS and not in megaloblastic anaemia and iron deficiency anaemia. This supports the recent view that $c-m y b$ is strictly linked to the proliferative rate of erythroid progenitors rather than to their stage of differentiation. ${ }^{17} \mathrm{C}$ ets is a proto-oncogene on chromosome 11q23 and active in erythroblastosis ${ }^{18}$ while the $a b l$ oncoprotein is a tyrosine kinase middle mes-

$C$-mos relative expression and survival. (A) $p<0.6$ (B) $p>0.6$

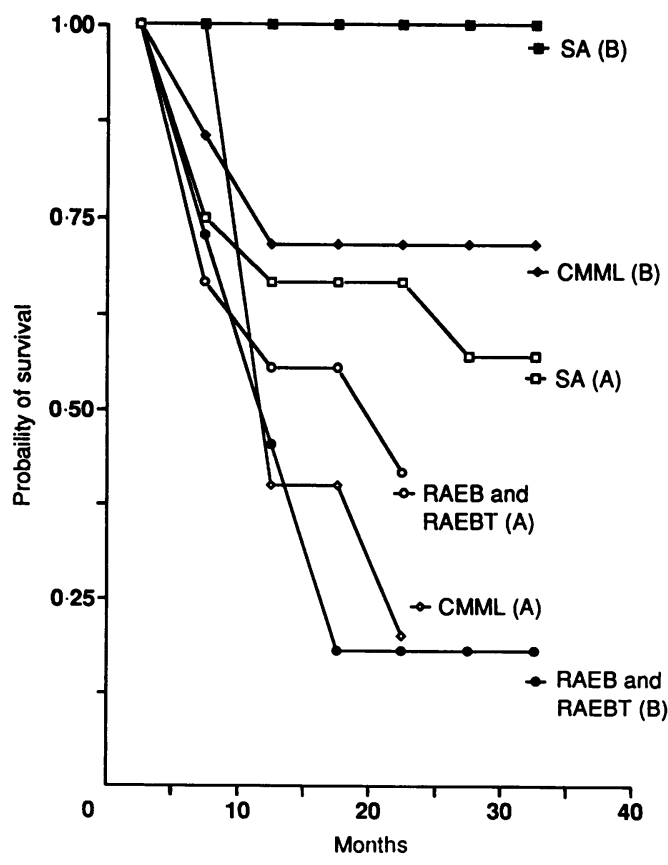

senger. Both could be increased with increased division and differentiation of erythroid cells in MDS, megaloblastic anaemia, and iron deficiency anaemia.

Only c-mos showed some correlation with the FAB subgroup. The $c$-mos probe used in this study was a murine genomic probe. This will hybridise to the human $c$-mos locus on $8 \mathrm{q}^{11^{19-20}}$ but may also hybridise to related sequences from the mos oncogene family. ${ }^{21} C$-mos oncoprotein is a cytoplasmic serine-threonine protein kinase middle messenger, a protein kinase-C linking the G-proteins to the nucleus and involved in multiple signalling pathways. ${ }^{22}$ $N$-ras mutation found in one third of patients with MDS switches on the signal for division permanently ${ }^{23}$ and $c$-mos may merely reflect this. ${ }^{24}$ However, $c$-mos induces progression of meiosis and mitosis in tissue culture; at low concentrations in stem cells it increases differentiation but at a high level of expression it leads to transformation. ${ }^{25-27}$ Both observations would explain the increasing $c$-mos expression in RA transforming to RAEBT. In addition, in our study $c$-mos concentrations were highest where there was a high monocyte count or monocytic differentiation, a scenario which reflected marrow stability with a longer patient survival (trend $p=0.079$ ).

Our attempts to correlate karotype with oncogene expression were restricted by small numbers. The relation between trisomy 8 and increased $c$-mos expression is most likely to have been due to gene amplification rather than translocation during progression from $M D S$ to $A M L$, as Morris found no evidence for the latter. ${ }^{19}$ We confirm the findings that loss of chromosome material was accompanied by a worse prognosis. ${ }^{28}$ In the small number progressing to AML $70 \%$ had abnormal karyotypes at presentation, and in $20 \%$ it became abnormal with change to AML: $80 \%$ had lost chromosome material; $20 \%$ developed trisomy 8.

MDS is a heterogeneous disorder with a mixture of clonal and non-clonal cell populations. ${ }^{29}$ Further studies using a cell sorter and in situ hybridisation are needed to elucidate the precise role of the increased oncogene expressions that we have observed.

We thank Drs Durrant, Mitchell, Wood and the medical and nursing staff of the haematology unit for providing patient data, received a grant from the Trent Regional Health Authority. 
1 LRF. Leukaemia and Lymphoma 1984-1988. London: Leukaemia Research, Fund: 1990.

2 Yunis JJ, Brunning RD. Prognostic significance of chromosomal abnormalities in acute leukaemias and myelodysplastic syndromes. Clin Haematol 1986;15: 597-620.

3 Pierce JH, Eva A, Aaaronson SA. Interactions of oncogenes with haemopoietic cells. Clin Haematol 1986;15:573-96.

4 Preisler HD, Raza A, Lawson R, et al. Proto-oncogene expression and the clinical characteristics of acute nonlymphocytic leukaemia. A leukaemia inter-group pilot study. Blood 1989;73:255-62.

5 Bar Eli M, Ahuja N, Gonzalex-Cadavid Foti A, Cline MJ. Analysis of N-RAS Exon-1 mutations in myelodysplastic syndromes by polymerase chain reaction and direct syndromes by polymerase chain

6 Layton DM, Mufti GJ, Lyons J, Janssen JWG, Bartram CR. Loss of Ras oncogene mutation in a myelodysplastic Loss of Ras oncogene mutation in a myelodysplastic syndrome after

7 Melani C, Haliassos A, Chomel JC, et al. Ras activation in myelodysplastic syndromes: Clinical and molecular study of the chronic phase of the disease. Br J Haematol 1990;74:408-13.

8 Ahuja HG, Fot A, Zhou DJ, Cline MJ. Analysis of protooncogene in acute myeloid leukaemia: Loss of heterozygosity for the ha-ras gene. Blood 1990;75:819-22.

9 Bennett JM, Catovsky D, Daniel MT, et al. Proposals for the classification of the myelodysplastic syndromes. $\mathrm{Br} J$ Haematol 1982;51:189-99.

10 Sambrook J, Fritsch EF, Maniatis T. Molecular cloning. New York: Cold Spring Harbour Laboratory Press, 1989:7.54-7.55.

11 Feinberg AP, Volgelstein B. A technique for radiolabelling DNA restriction endonuclease fragments to high specific activity. Anal Biochem 1984;137:266-7.

12 Grosso LE, Pitot HC. Modulation of c-myc expression in the HL-60 cell line. Biochim Biophys Res Commun 1984;119:473-80.

13 Brown PC, Tisty TD, Schimatre ET. Enhancement of methotrexate resistance and dihydrofolate reductase gene amplification by treatment of mouse $3 \mathrm{~Tb}$ cells with hydroxyurea. Mol Cell Biol 1983;3:1097.

14 Bains MA, Hoy TG, Baines P, Jacobs A. Nuclear c-myc protein, maturation, and cell cycle status of human haemopoietic cells. Br J Haematol 1987;61:293-300.

15 Emelia G, Donelli A, Ferrari S, et al. Cellular levels of mRNA from c-myc, c-myb and c-fes oncogenes in normal myeloid and erythroid precursors of human bone marrow: myeloid and erythroid precursors of human bone marrow: an in situ hy

16 Izak G. Erythroid cell differentiation and maturation. Progr Haematol 1977;10:1-41.

17 Valtien M, Venturelli D, Care A, et al. Antisense myb inhibition of purified erythroid progenitors in development and differentiation is linked to cycling activity and expression of DNA polymerase. Blood 1991;77:1181-90.

18 de Taisne C, Gegonne A, Stehelin D. Chromosoma localization of the human proto-oncogene c-ets. Nature 1984;310:581-3.

19 Morris CM, Bowen J, Fitzgerald PH. Localization of human c-mos to chromosome band 8q11 in leukaemic cells with the $(8 \cdot 21)(q 22: q 22)$. Hum Genet 1989;81:339-42.

20 Testa JR, Parsa NZ, Le Beau MM, Vande Woude GF.
Localization of the proto-oncogene mos to $8 q 11-q 12$ by in situ chromosomal hybridization. Genomic 1988;3:44-7.

21 Berdichevskii FB, Chumakow IM, Kiselev LL. Decoding of the primary structure of the son 3 region in human genome: identification of a new protein with unusual genome: identification of a new protein with unusual Btructure and homology

22 Druker BJ, Harvey J, Mamon BS, Roberts TM. Oncogenes growth factors and signal transduction. $N$ Engl $J$ Med 1989;321:1383-91.

23 Jacobs A. Oncogenes in myelodysplastic syndrome. Blood Rev 1989;3:105-9.

24 Chenevix-Trench G, Southall M, Kidson C. The Eco R RFLP of c-mos in patients with non-Hodgkin's lym phoma and acute lymphoblastic leukaemia, compared to geriatric and non-geriatric controls. Int $J$ Cancer 1989;43:1034-6.

25 Freeman RS, Pickman KM, Kanki JP. Xenopus homolog of the mos proto-oncogene transforms mammalian fibroblasts and induces maturation of xenopus oocytes. Proc Natl Acad Sci USA 1989;86:5805-9.

26 Kurate N Akiyama H, Taniyama T, Marunoachi T. Dose dependent regulation of macrophage differentiation by dependent regulation of macrophage differentiation by mos RNA in

27 O'Hara BM, Blair DG. A threshold effect in the induction of tumourigenicity of an established human cell line by vmos. Oncogene 1988;3:295-9.

28 Clark R, Peters S, Hoy T, Smith S, Whittaker K, Jacobs A. Prognostic importance of hypodiploid haemopoietic precursors in myelodysplastic syndromes. $N$ Engl J Med 1986;314:1472-5.

29 Temin HM. Evolution of cancer genes by a mutation-driven process. Cancer Res 1988;48:1697-701.

30 Reddy ER, Smith MJ, Srinivasan A. Nucleotide sequence of Abelson Murine leukaemia virus genome: Structural similarity of its transforming gene product to other similarity of its trans with tyrosine-specific kinase activity. oncogene products with tyrosine-specific kinase activity. (correction)

31 Yu YH, Ishii S, Clark AJ, et al. Human epidermal growth factor receptor cDNA is homologous to a variety of RNAs overproduced in A431 carcinoma cells. Nature 1984;309:806-10

32 de Taisne C, Gegonne A, Stehelin D. Chromosomal localization of the human proto-oncogene c-ets. Nature 1984;310:581-3.

33 Oskarsson M, McClements WL, Blair DG, Maizel JV, Vande Woude GF. Properties of a normal mouse cell DNA sequence (Sarc) homologous to the Src sequence of Moloney sarcoma virus. Science 1980;207:1222-4.

34 Trus MD, Sodroski JG, Haseltine WA. Isolation and characterisation of a human locus homolgous to the transforming gene (v-fes) of feline sarcoma virus. J Biol transforming gene (v-fes)

35 Dalla-Favera R, Westin E, Gelmann EP, et al. The human oncogene c-myc: structure, expression and amplification in oncogene c-myc: structure, expression and amplification in the human promyelocytic leukaemia cell

36 Klematol Blut Transfus 1983;28:246-54. klempnauer $\mathrm{KH}$, Gonda TJ, Bishop JM. Nucleotide
sequence of the retroviral leukaemic gene v-myb and its cellular progenitor c-myb: the architecture of a transduced oncogene. Cell 1982;31:453-63. 